\title{
Traditional predictors of in-hospital mortality after coronary artery bypass grafting: Current status
}

\author{
Yasser Ali Kamal ${ }^{*}$, Shady Al-Elwany ${ }^{1}$, Ahmed Ghoneim ${ }^{2}$ and Ahmed El-Minshawy ${ }^{2}$ \\ ${ }^{1}$ Department of Cardiothoracic Surgery, Minia University Hospital, Egypt \\ ${ }^{2}$ Professor, Department of Cardiothoracic Surgery, Assiut University Hospital, Egypt
}

\begin{abstract}
The most serious early adverse events after coronary artery bypass grafting (CABG) include in-hospital mortality, low cardiac output, perioperative myocardial infarction, renal dysfunction, stroke, atrial fibrillation and sternal wound infection. Prediction of outcome after CABG has a considerable importance which constitutes guidance for proper perioperative care and improved postoperative outcome. Advances in anesthesia and surgical techniques play a role in enrollment of patients with higher risk for $\mathrm{CABG}$ which indicates periodic updating of the traditional predictors of outcome. This review tries to highlight the current status of the important preoperative predictors of early mortality and morbidity after CABG.
\end{abstract}

Abbreviations: AF: Atrial Fibrillation; BMI: Body Mass Index; CABG: Coronary Artery Bypass Grafting; CAD: Coronary Artery Disease; CCS: Canadian Cardiovascular Society; COPD: Chronic Obstructive Pulmonary Disease; CPB: Cardiopulmonary Bypass; $\mathrm{CrCl}$ : Creatinine Clearance; cTn: cardiac troponin; DM: Diabetes Mellitus; EuroSCORE: European System for Cardiac Operative Risk valuation; HbA1c: Haemoglobin A1c; IABP: Intra-Aortic Balloon Pump; LCOS: Low cardiac output syndrome; LMS: Left Main Stem; LVD: Left Ventricular Dysfunction; LVEF: Left Ventricular Ejection Fraction; NSTEMI: Non-ST Elevation Myocardial Infarction; PMI: Perioperative Myocardial Infarction; POAF: Postoperative Atrial Fibrillation; PVD: Peripheral Vascular Disease; SBP: Systolic Blood Pressure; SWI: Sternal Wound Infection.

\section{Introduction}

Awareness of perioperative risk factors associated with mortality and morbidity after cardiac surgery is an important issue that may provide valuable insights on areas to focus for better outcome and improved quality of care [1].

Research for perioperative predictors of outcome results in establishment of multiple risk stratification models, of which European system for cardiac operative risk evaluation (EuroSCORE) and Parsonnet score (Table 1) are the most frequently used models [2,3].

In the recent years more, complex preoperative patient profile had been referred for coronary artery bypass (CABG) including older patients, more advanced and diffuse coronary artery disease, impaired left ventricular function, failed previous percutaneous manipulations, more serious comorbidities, and multiple reoperations [4].

The increasing complexity and disability of patients is an important reason for periodic update of the perioperative predictors to account for the changes in patient characteristics and contemporary surgical techniques $[5,6]$. The aim of this review is to highlight the current status of the established preoperative predictors of adverse outcome after CABG.

\section{Predictors of in-hospital mortality after CABG}

\section{Age at surgery}

Respecting more extensive coronary atherosclerosis, older age has been recognized as an independent predictor of short- and long-term mortality and adverse outcome after CABG $[7,8]$.

Although age of 60 years is traditionally considered as a cut-off value for worse outcome after CABG, other values of $65,70,75$ or 80 years has been recognized, mostly due to the decline in operation risks thanks to the advances of technology, methods and proper selection of patients $[9,10]$.

\section{Female gender}

Female gender is still recognized as an independent predictor of short- and long-term mortality and adverse events after CABG $[11,12]$. The gender-specific differences in outcome may be aggravated by older age, advanced symptoms, urgency, coronary artery diameters, as well as higher incidence of comorbidities such as diabetes, arterial hypertension and hypercholesterolemia [13].

\section{Obesity}

Obesity defined as body mass index (BMI) $\geq 30 \mathrm{~kg} / \mathrm{m}^{2}$ has been reported to be associated with increased pulmonary morbidity [14] and severe obesity $\left(\mathrm{BMI} \geq 40 \mathrm{~kg} / \mathrm{m}^{2}\right.$ ) has been determined as an independent risk factor for longer length of stay after CABG [15].

Correspondence to: Yasser Ali Kamal, Department of Cardiothoracic Surgery, Minia Cardiothoracic University Hospital, El-Minya El-Jadeda, 61768, Minia, Egypt, Tel: 002-01123234736; Fax: 20-086 2342501; E-mail: yaser_ ali_kamal@yahoo.com

Key words: coronary artery bypass grafting, outcome, predictors

Received: December 01, 2017; Accepted: December 18, 2017; Published: December 22, 2017 
Table 1. The established predictors of mortality after cardiac surgery as determined in EuroSCORE and Parsonnet score models for risk stratification. Modified from references [2,3].

\begin{tabular}{|c|c|c|c|}
\hline \multicolumn{2}{|l|}{ EuroSCORE } & \multicolumn{2}{|l|}{ Parsonnet Score } \\
\hline Risk factors & Score & Risk factors & Score \\
\hline \multicolumn{4}{|l|}{ Patient related factors: } \\
\hline Age: & & Age: & \\
\hline \multirow[t]{3}{*}{ Per each 5 years above 60 years } & 1 & $<70$ years & 7 \\
\hline & & 71-74 years & 12 \\
\hline & & 75 years & 20 \\
\hline Female gender & 1 & Female gender & 1 \\
\hline Serum creatinine $>2.3 \mathrm{mg}$ preoperatively & 2 & Dialysis dependency & 10 \\
\hline $\begin{array}{l}\text { Critical preoperative state (ventricular tachycardia or fibrillation, aborted } \\
\text { sudden death, or preoperative heart massage, ventilation, inotropic support } \\
\text { or IABP }\end{array}$ & 3 & $\begin{array}{l}\text { Catastrophic states (acute structural defect, cardiogenic shock, acute } \\
\text { renal failure or similar conditions) }\end{array}$ & Oct-50 \\
\hline Neurological dysfunction affecting walking or daily activities & 2 & $\begin{array}{l}\text { Other rare circumstances (paraplegia, pacemaker dependency, severe } \\
\text { asthma, congenital heart disease in adults) }\end{array}$ & 02-Oct \\
\hline $\begin{array}{l}\text { Extracardiac arteriopathy: claudication or obstruction }>50 \% \text { of carotid } \\
\text { arteries or previous or planned intervention for abdominal aorta, carotid } \\
\text { arteries or peripheral arteries }\end{array}$ & 2 & Preoperative IABP & 20 \\
\hline $\begin{array}{l}\text { Active endocarditis patient still under antibiotic treatment for endocarditis at } \\
\text { the time of surgery }\end{array}$ & 1 & Morbid obesity ( $\geq 1.5$ of ideal weight) & 3 \\
\hline \multirow[t]{2}{*}{ Chronic pulmonary disease } & 3 & Diabetes & 3 \\
\hline & & Hypertension (Systolic blood pressure $>140 \mathrm{mmHg}$ ) & 3 \\
\hline \multicolumn{4}{|l|}{ Cardiac related factors } \\
\hline Ejection fraction: & & Ejection fraction: & \\
\hline $30-50 \%$ & 1 & $30-49 \%$ & 2 \\
\hline$<30 \%$ & 3 & $<30 \%$ & 4 \\
\hline \multicolumn{4}{|l|}{ Pulmonary hypertension: Systolic pressure of pulmonary artery $>60 \mathrm{mmHg}$} \\
\hline Unstable angina requiring use of nitrates before arrival to operating room & 2 & & \\
\hline Recent $\mathrm{MI}<90$ days & 2 & & \\
\hline \multicolumn{4}{|l|}{ Procedure related factors } \\
\hline Emergency within 24 hours & 2 & Catheter lab emergency & 10 \\
\hline Reoperation: & & Reoperation: & \\
\hline \multirow[t]{2}{*}{ Requiring opening of the pericardium } & 3 & First & 5 \\
\hline & & Second & 10 \\
\hline Another heart procedure at the same time as CABG & 2 & CABG at time of valve surgery & 2 \\
\hline Surgery on thoracic aorta for disorder of ascending, arch or descending aorta & 3 & Aortic surgery & 5 \\
\hline \multirow[t]{4}{*}{ Post-infarction VSD } & 4 & LV aneurysm & 5 \\
\hline & & Aortic surgery and aortic gradient $\geq 120 \mathrm{mmHg}$ & 7 \\
\hline & & Mitral surgery & 5 \\
\hline & & Mitral surgery and PA pressure $\geq 60 \mathrm{mmHg}$ & 8 \\
\hline
\end{tabular}

The impact of obesity on early mortality after CABG remains uncertain [16]. Obesity has not been associated with increased inhospital or 3 months mortality [17], while morbid obesity was recognized as an independent predictor for late mortality after CABG [18].

Compared to non-obese patients, overweight and obese individuals have similar early mortality rate following CABG which can substantiate the presence of obesity paradox only in terms that elevated BMI patients have comparable outcome with non-obese [19].

\section{Diabetes mellitus}

Patients with diabetes and CAD often have more extensive and complicated atherosclerosis, thus they are at higher risk of developing major adverse events and death after CABG with prolonged hospital stay and greater hospital costs than are patients without diabetes [20].

Diabetes on insulin treatment is considered as a predictor of outcome after cardiac surgery [21]. Patients with insulin treated DM have a significantly higher rate of mortality and major adverse events compared to patients with non-insulin treated DM patients after CABG [22].

Elevated preoperative haemoglobin $\mathrm{A} 1 \mathrm{c}(\mathrm{HbAlc})$ is debated as a predictor of mortality and morbidity irrespective of previous diabetic status. In particular, the mortality risk for CABG is quadrupled at $\mathrm{HbA1c}$ levels $>8.6 \%$ [23]. In a recent study preoperative HbAlc was the only diabetic variable to independently predict operative mortality after CABG [24].

\section{Hypertension}

Isolated systolic hypertension (systolic blood pressure (SBP) $>140$ $\mathrm{mmHg}$ ) only was reported to be associated with adverse outcomes after CABG, causing a $40 \%$ increase in the likelihood of postoperative morbidity [25]. Recent studies reported hypertension among risk factors associated with early mortality in haemodialysis patients undergoing CABG [26], and it has been considered with other demographic risk factors among predictors of AF after CABG [27].

\section{Chronic obstructive pulmonary disease}

Chronic obstructive pulmonary disease (COPD) is traditionally established as a predictor of postoperative morbidity and mortality after CABG surgery, especially in patients older than 75 years with severe COPD and receiving steroids [28].

The known postoperative complications of COPD include respiratory failure, re-intubation, sternal dehiscence, prolonged 
mechanical ventilation, rhythm disturbances and prolonged hospital stays [29]. A recent study reported that COPD does not necessarily lead to mortality, readmission, or AMI after CABG, and the major respiratory complications associated with CABG in patients with COPD were pneumonia and acute respiratory failure [30].

\section{Extra-cardiac arteriopathy}

Evidence from recent studies suggests that peripheral vascular disease (PVD) still adversely affects the short- and long-term outcomes after CABG [31]. However, diversity of symptoms as well as the severity and location of occluded vessels may influence outcome [32].

Carotid artery disease is considered as an epiphenomenon that serves as a marker for diffuse systemic atherosclerotic disease [33]. Extracranial carotid artery stenosis (CAS) is a risk factor for perioperative stroke in patients undergoing CABG surgery [34]. In patients with $50 \%$ to $80 \%$ stenosis of the carotid arteries, the incidence of stroke after CABG ranged from $3 \%$ to $10 \%$, and approached $22 \%$ in patients with $>80 \%$ stenosis [35].

\section{Neurological dysfunction}

Preoperative neurological events are determined as risk factors for postoperative neurologic events and in-hospital mortality particularly with cardiopulmonary bypass [36].

Preoperative stroke was reported to be associated with mortality, increased risk of early and late postoperative stroke, and prolonged length of stay [37]. However, optimal time interval between stroke and surgery has a debate, as there is no contemporary evidence that more recent preoperative stroke predisposed patients undergoing CABG to have adverse perioperative outcomes [38].

\section{Chronic renal impairment}

Preoperative renal impairment is a well-established predictor of adverse events in after CABG [39]. However, when compared with expected survival, only advanced renal impairment led to worse outcome, and patients with moderate renal impairment had an outcome similar to that expected [40].

Serum creatinine is a main predicting factor in the scoring systems for risk estimation with a significant impact on surgical outcome after cardiac surgery [41]. For a better estimate of kidney failure degree, current risk scores, such as EuroSCORE II, have included creatinine clearance $(\mathrm{CrCl})$ calculation rather than serum creatinine to predict mortality after cardiac surgery $[42,43]$.

Cystatin $\mathrm{C}$ which is less affected by dietary protein intake has been shown to have a greater predictive power than serum creatinine for overall mortality after elective CABG [44].

\section{Left main stem disease}

A significant Left main stem (LMS) disease, defined as reduction of $\geq 50 \%$ of the vessel diameter, is an important predictor of cardiopulmonary morbidity and mortality after CABG [45]. Multiple clinical variables have been shown as prognostic factors in LMS lesion, including: cardiogenic shock, ST-elevation MI, reduced LVEF, older age, multi-vessel disease, and diabetes mellitus [46].

\section{Severity of angina}

High Canadian Cardiovascular Society (CCS) class of angina before CABG is still determined as an independent predictor of adverse outcome and quality of life after CABG [47].
Acute coronary syndrome (unstable angina and non-ST-segment elevation myocardial infarction) is determined as an independent predictor of early mortality, however the long-term outcomes after CABG are similar between patients with acute coronary syndrome and stable angina [48].

\section{Perioperative myocardial infarction}

Perioperative myocardial infarction (PMI) is a well-known cause of morbidity and mortality after CABG surgery [49]. Ninety days threshold is traditionally accepted as minimal time interval between MI and CABG [20]. However, a recent study showed that patients operated on 1 to 2 days and 3 to 7 days after MI had a similar mortality rate [50].

It has been suggested that CABG may be safely performed in nonST elevation myocardial infarction (NSTEMI) patients at any time after the first 6 hours of the event in patients with cardiac troponin I (cTnI) $<0.15 \mathrm{ng} / \mathrm{ml}$ [51]. The contemporary findings show that it is safe to wait until cTnT levels decrease to the $1 \mathrm{ng} / \mathrm{ml}$ threshold value in $\mathrm{cTnT}$ positive patients having a stable course [52].

\section{Urgency of CABG}

Urgency of CABG (urgent, emergent or salvage operation) was determined as a significant predictor of outcome after CABG in Euroscore II risk model [53]. Urgency is associated with significantly higher adverse outcomes, including death, when compared with elective CABG [54].

Early mortality in patients undergoing emergent and salvage CABG is substantial, especially in salvage patients. Long-term survival is acceptable in both emergent and salvage patients [55].

\section{Low left ventricular ejection fraction (LVEF)}

Preoperative low LVEF is still an important predictor of mortality and morbidity after CABG $[56,57]$. However, surgery remains superior to medical therapy alone in patients with low LVEF [58,59]. Accurate selections of patients and risk/benefit evaluation, as well as planning of surgical and anesthesiological management are mandatory to improve outcome [60].

\section{Conclusions}

Predicting outcome after CABG is multifactorial. In the current literature, traditional predictors of adverse outcome are subjected to isolated or combined revision and validation. The cut-off value of age as a predictor of worse outcome does not be stand at 60 years. The predictive value of female gender is further investigated in respecting of gender difference in preoperative comorbidities. A debate exists regarding the impact of obesity on early outcome after CABG. Not only suffering from DM, but also elevation of preoperative $\mathrm{HbA1c}$ has a useful predictive value. The role of COPD in predicting outcome is related to presence of other risk factors especially older age and steroid therapy. Carotid artery stenosis $>50 \%$ remains a significant predictor of postoperative stroke. The optimal time interval between preoperative stroke and CABG is still under debate. The predictive role of serum creatinine is questionable in comparison to creatinine clearance and Cystatin C. Left main stem disease $\geq 50 \%$, severity of angina, perioperative MI, urgency of surgery and low preoperative LVEF are still recognized as important predictors of adverse outcome after CABG. Timing between NSTEMI and CABG is related to reduction of the level of cardiac troponin. In patients with low LVEF, proper selection of patients for surgery and myocardial viability still has a 
great influence on outcome after CABG. Searching for more predictors related to the current practical era and updating the established risk models of adverse outcome after CABG is highly recommended.

\section{Conflict of Interest}

Author Yasser Ali Kamal declares that he has no conflict of interest. Author Shady Al-Elwany declares that he has no conflict of interest. Author Ahmed Ghoneim declares that he has no conflict of interest. Author Ahmed El-Minshawy declares that he has no conflict of interest.

\section{Funding}

None

\section{Ethical approval}

This article does not contain any studies with human participants or animals performed by any of the authors.

\section{Informed consent}

Non-applicable. This article does not contain any studies with human participants performed by any of the authors.

\section{References}

1. Antunes PE, de Oliveira JF, Antunes MJ (2009) Risk-prediction for postoperative major morbidity in coronary surgery. Eur J Cardiothorac Surg 35: 760-768. [Crossref]

2. Nashef SA1, Roques F, Michel P, Gauducheau E, Lemeshow S, et al. (1999) European system for cardiac operative risk evaluation (EuroSCORE). Eur J Cardiothorac Surg 16: 9-13. [Crossref]

3. Parsonnet V, Dean D, Bernstein AD (1989) A method of uniform stratification of risk for evaluating the results of surgery in acquired adult heart disease. Circulation 79: I3-12. [Crossref]

4. Rushing GD, Yuh DD (2014) Primary Coronary Artery Bypass Surgery. In: Yuh DD, Vricella LA, Yang SC, Doty JR (eds). Johns Hopkins Textbook of Cardiothoracic Surgery, 2nd edition. McGraw-Hill Education, New York P: 414-432.

5. Algarni KD, Elhenawy AM, Maganti M, Collins S, Yau TM (2012) Decreasing prevalence but increasing importance of left ventricular dysfunction and reoperative surgery in prediction of mortality in coronary artery bypass surgery: trends over 18 years. J Thorac Cardiovasc Surg 144: 340-346. [Crossref]

6. Weisel RD, Nussmeier N, Newman MF, Pearl RG, Wechsler AS, et al. (2014) Predictors of contemporary coronary artery bypass grafting outcomes. J Thorac Cardiovasc Surg 148: 2720-2726.e1-2. [Crossref]

7. Flather M, Rhee JW, Boothroyd DB, Boersma E, Brooks MM, et al. (2012) The effect of age on outcomes of coronary artery bypass surgery compared with balloon angioplasty or bare-metal stent implantation among patients with multivessel coronary disease. J Am Coll Cardiol 60: 2150-2157. [Crossref]

8. Miskowiec D, Walczak A, Ostrowski S, Wrona E, Bartczak K, et al. (2014) Isolated coronary artery bypass grafting in extracorporeal circulation in patients over 65 years old-does age still matter? Kardiochir Torakochirurgia Pol 11:191-199. [Crossref]

9. Rocha AS, Pittella FJ, Lorenzo AR, Barzan V, Colafranceschi AS, et al. (2012) Age influences outcomes in 70-year or older patients undergoing isolated coronary artery bypass graft surgery. Rev Bras Cir Cardiovasc 27: 45-51. [Crossref]

10. Safaie N, Montazerghaem H, Jodati A, Maghamipour N (2015) In-Hospital Complications of Coronary Artery Bypass Graft Surgery in Patients Older Than 70 Years. J Cardiovasc Thorac Res 7: 60-62. [Crossref]

11. Alam M, Bandeali SJ, Kayani WT, Ahmad W, Shahzad SA, et al. (2013) Comparison by meta-analysis of mortality after isolated coronary artery bypass grafting in women versus men. Am J Cardiol 112: 309-317. [Crossref]

12. Ergunes K, Yilik L, Yetkin U, Lafci B, Bayrak S, et al. (2014) Early and Mid-term Outcomes in Female Patients Undergoing Isolated Conventional Coronary Surgery. $J$ Cardiovasc Thorac Res 6: 105-110. [Crossref]

13. Solimene MC (2010) Coronary heart disease in women: a challenge for the $21 \mathrm{st}$ century. Clinics (Sao Paulo) 65: 99-106. [Crossref]
14. Devarajan J, Vydyanathan A, You J, Xu M, Sessler DI, et al. (2016) The association between body mass index and outcome after coronary artery bypass grafting operations. Eur J Cardiothorac Surg 50: 344-349. [Crossref]

15. Terada T, Johnson JA, Norris C, Padwal R, Qiu W, et al. (2016) Severe Obesity Is Associated with Increased Risk of Early Complications and Extended Length of Stay Following Coronary Artery Bypass Grafting Surgery. J Am Heart Assoc 5: e003282. [Crossref]

16. Furnaz S (2014) PCV21-Body Mass Index (BMI) as A Predictor of Outcome after Coronary Artery Bypass Grafting: An Asian Perspective. Value in Health 17: A759.

17. Ardeshiri M, Faritous Z, Ojaghi Haghighi Z, Hosseini S, Baghaei R (2014) Effect of obesity on mortality and morbidity after coronary artery Bypass grafting surgery in Iranian patients. Anesth Pain Med 2014 4: e18884. [Crossref]

18. van Straten AH, Bramer S, Soliman Hamad MA, van Zundert AA, Martens EJ, et al. (2010) Effect of body mass index on early and late mortality after coronary artery bypass grafting. Ann Thorac Surg 89: 30-37. [Crossref]

19. Cemerlić-Adjić N, Pavlović K, Jevtić M, Velicki R, Kostovski S, et al. (2014) The impact of obesity on early mortality after coronary artery bypass grafting. Vojnosanit Pregl 71: 27-32. [Crossref]

20. Nashef SA, Roques F, Sharples LD, Nilsson J, Smith C, et al. (2012) EuroSCORE II. Eur J Cardiothorac Surg 41: 734-744. [Crossref]

21. Munnee K, Bundhun PK, Quan H, Tang Z (2016) Comparing the Clinical Outcomes Between Insulin-treated and Non-insulin-treated Patients with Type 2 Diabetes Mellitus After Coronary Artery Bypass Surgery: A Systematic Review and Metaanalysis. Medicine (Baltimore) 95: e3006. [Crossref]

22. Raza S, Sabik JF 3rd, Ainkaran P, Blackstone EH (2015) Coronary artery bypass grafting in diabetics: A growing health care cost crisis. J Thorac Cardiovasc Surg 150: 304-302. [Crossref]

23. Tennyson C, Lee R, Attia R (2013) Is there a role for HbAlc in predicting mortality and morbidity outcomes after coronary artery bypass graft surgery? Interact Cardiovasc Thorac Surg 17: 1000-1008. [Crossref]

24. Wang TK, Woodhead A, Ramanathan T, Pemberton J (2016) Relationship Between Diabetic Variables and Outcomes After Coronary Artery Bypass Grafting in Diabetic Patients. Heart Lung Circ 26: 371-375. [Crossref]

25. Aronson S, Boisvert D, Lapp W (2002) Isolated systolic hypertension is associated with adverse outcomes from coronary artery bypass grafting surgery. Anesth Analg 94 1079-1084. [Crossref]

26. Cevirme D, Adademir T, Aksut M, Orki T, Çakalagaoglu KC, et al. (2016) Factors associated with early mortality in haemodialysis patients undergoing coronary artery bypass surgery. Cardiovasc J Afr 27: 1-4. [Crossref]

27. Perrier S, Meyer N, Hoang Minh T, Announe T, Bentz J, et al. (2016) Predictors of Atrial Fibrillation After Coronary Artery Bypass Grafting: A Bayesian Analysis. Ann Thorac Surg 103: 92-97. [Crossref]

28. Samuels LE, Kaufman MS, Morris RJ, Promisloff R, Brockman SK (1998) Coronary artery bypass grafting in patients with COPD. Chest 113: 878-882. [Crossref]

29. Bingol H, Cingoz F, Balkan A, Kilic S, Bolcal C, et al. (2005) The effect of oral prednisolone with chronic obstructive pulmonary disease undergoing coronary artery bypass surgery. J Card Surg 20: 252-256. [Crossref]

30. Ho CH, Chen YC, Chu CC, Wang JJ, Liao KM (2016) Postoperative Complications After Coronary Artery Bypass Grafting in Patients with Chronic Obstructive Pulmonary Disease. Medicine (Baltimore) 95: e2926. [Crossref]

31. Nakatsu T, Tamura N, Yanagi S, Kyo S, Koshiji T, et al. (2014) Bilateral interna thoracic artery grafting for peripheral arterial disease patients. Gen Thorac Cardiovasc Surg 62: 481-487. [Crossref]

32. Huang CL, Wu IH, Wu YW, Hwang JJ, Wang SS, et al. (2014) Association of lower extremity arterial calcification with amputation and mortality in patients with symptomatic peripheral artery disease. PLoS One 9: e90201. [Crossref]

33. Forbes TL, Ricco JB (2010) Trans-Atlantic debate: is carotid artery disease responsible for perioperative strokes after coronary artery bypass surgery? Eur J Vasc Endovasc Surg 40: 695. [Crossref]

34. Roffi M, Ribichini F, Castriota F, Cremonesi A (2012) Management of combined severe carotid and coronary artery disease. Curr Cardiol Rep 14: 125-134. [Crossref]

35. da Rosa MP, Schwendler R, Lopes R, Portal VL (2013) Carotid Artery Stenosis Associated with Increased Mortality in Patients who underwent Coronary Artery Bypass Grafting: A Single Center Experience. Open Cardiovasc Med J 7: 76-81. [Crossref] 
36. Halkos ME, Puskas JD, Lattouf OM, Kilgo P, Guyton RA, et al. (2008) Impact of preoperative neurologic events on outcomes after coronary artery bypass grafting. Ann Thorac Surg 86: 504-510. [Crossref]

37. Anyanwu AC, Filsoufi F, Salzberg SP, Bronster DJ, Adams DH (2007) Epidemiology of stroke after cardiac surgery in the current era. J Thorac Cardiovasc Surg 134: 11211127. [Crossref]

38. Bottle A, Mozid A, Grocott HP, Walters MR, Lees KR, et al. (2013) Preoperative Stroke and Outcomes after Coronary Artery Bypass Graft Surgery. Anesthesiol 118: 885-893. [Crossref]

39. Holzmann MJ, Sartipy U (2013) Relation between preoperative renal dysfunction and cardiovascular events (stroke, myocardial infarction, or heart failure or death) within three months of isolated coronary artery bypass grafting. Am J Cardiol 112: 1342-1346. [Crossref]

40. Minakata K, Bando K, Tanaka S, Takanashi S, Konishi H, et al. (2014) Preoperative chronic kidney disease as a strong predictor of postoperative infection and mortality after coronary artery bypass grafting. Circ J 78: 2225-2231. [Crossref]

41. Nilsson J, Algotsson L, Höglund P, Lührs C, Brandt J (2006) Comparison of 19 preoperative risk stratification models in open-heart surgery. Eur Heart J 27: 867-874. [Crossref]

42. Shahian DM, O'Brien SM, Filardo G, Ferraris VA, Haan CK, et al. (2009) The Society of Thoracic Surgeons 2008 cardiac surgery risk models: part 1--coronary artery bypass grafting surgery. Ann Thorac Surg 8: S2-22. [Crossref]

43. Nashef SA, Roques F, Sharples LD, Nilsson J, Smith C, et al. (2012) EuroSCORE II. Eur J Cardiothorac Surg 41: 734-744. [Crossref]

44. Dardashti A, Nozohoor S, Algotsson L, Ederoth P, Bjursten H (2016) The predictive value of s-cystatin $\mathrm{C}$ for mortality after coronary artery bypass surgery. $J$ Thorac Cardiovasc Surg 152: 139-146. [Crossref]

45. Sher-I-Murtaza M, Baig MA, Raheel HM (2015) Early outcome of Coronary Artery Bypass Graft Surgery in patients with significant Left Main Stem stenosis at a tertiary cardiac care center. Pak J Med Sci 31: 909-914. [Crossref]

46. Karabulut A, Cakmak M (2015) Treatment strategies in the left main coronary artery disease associated with acute coronary syndromes. J Saudi Heart Association 27: 272276. [Crossref]

47. Yilmaz S, Aksoy E, Dogan T, Diken AI, Yalcinkaya A, et al. (2016) Angina severity predicts worse sleep quality after coronary artery bypass grafting. Perfusion 31 : 471476. [Crossref]

48. Fukui T, Tabata M, Morita S, Takanashi S (2013) Early and long-term outcomes of coronary artery bypass grafting in patients with acute coronary syndrome versus stable angina pectoris. J Thorac Cardiovasc Surg 145: 1577-1583. [Crossref]
49. Jarvinen O, Hokkanen M, Huhtala H (2014) The long-term effect of perioperative myocardial infarction on health-related quality-of-life after coronary artery bypass grafting. Interact Cardiovasc Thorac Surg 18: 568-573. [Crossref]

50. Nichols EL, McCullough JN, Ross CS, Kramer RS, Westbrook BM, et al. (2017) Optimal Timing from Myocardial Infarction to Coronary Artery Bypass Grafting on Hospital Mortality. Ann Thorac Surg 103: 162-171. [Crossref]

51. Dayan V, Soca G, Parma G, Mila R (2013) Does early coronary artery bypass surgery improve survival in non-ST acute myocardial infarction? Interact Cardiovasc Thorac Surg 17: 140-142. [Crossref]

52. Ozbek IC, Sever K, Demirhan O, Mansuroglu D, Cicek M, et al. (2016) Timing of coronary artery bypass surgery in patients with non-ST-segment elevation myocardia infarction and postoperative outcomes. Arch Med Sci 12: 766-771. [Crossref]

53. Schumer EM, Chaney JH, Trivedi JR, Linsky PL, Williams ML, et al. (2016) Emergency Coronary Artery Bypass Grafting: Indications and Outcomes from 2003 through 2013. Tex Heart Inst J 43:214-219. [Crossref]

54. Axelsson TA, Mennander A, Malmberg M, Gunn J, Jeppsson A, et al. (2016) Is emergency and salvage coronary artery bypass grafting justified? The Nordic Emergency/Salvage coronary artery bypass grafting study. Eur J Cardiothorac Surg 49: 1451-1456. [Crossref]

55. Hamad MA, van Straten AH, Schonberger JP, ter Woorst JF, de Wolf AM, et al. (2010) Preoperative ejection fraction as a predictor of survival after coronary artery bypass grafting: comparison with a matched general population. J Cardiothorac Surg 5: 29. [Crossref]

56. Salehi M, Bakhshandeh A, Rahmanian M, Saberi K, MD, Kahrom M, et al. (2016) Coronary Artery Bypass Grafting in Patients with Advanced Left Ventricular Dysfunction: Excellent Early Outcome with Improved Ejection Fraction. J Tehran Heart Cent 11: 6-10. [Crossref]

57. Kamal YA, Al-Elwany SM, Ghoneim AF, El-Minshawy AK (2017) Predictors of adverse effects after coronary artery bypass grafting in patients with reduced left ventricular ejection fraction. J Egypt Soc Cardiothorac Surg 25: 20-27.

58. Wrobel K, Stevens SR, Jones RH, Selzman CH, Lamy A, et al. (2015) Influence of Baseline Characteristics, Operative Conduct and Postoperative Course on 30-day Outcomes of Coronary Artery Bypass Grafting among Patients with Left Ventricular Dysfunction: Results from the Surgical Treatment for Ischemic Heart Failure (STICH) Trial. Circulation 132: 720-730. [Crossref]

59. Gatti G, Maschietto L, Dell'Angela L, Benussi B, Forti G, et al (2016) Predictors of immediate and long-term outcomes of coronary bypass surgery in patients with left ventricular dysfunction. Heart Vessels 31: 1045-1055. [Crossref]

60. Pieri M, Belletti A, Monaco F, Pisano A, Musu M, et al. (2016) Outcome of cardiac surgery in patients with low preoperative ejection fraction. BMC Anesthesiol 16: 97. [Crossref]

Copyright: $\odot 2017$ Kamal YA. This is an open-access article distributed under the terms of the Creative Commons Attribution License, which permits unrestricted use, distribution, and reproduction in any medium, provided the original author and source are credited. 